\title{
Givenness, Saturation, and the Self: A Phenomenology of Christian Initiation
}

\author{
William C. Woody
}

Citation: Woody, William C. 2021. Givenness, Saturation, and the Self: A Phenomenology of Christian Initiation. Religions 12: 642. https:// doi.org/10.3390/rel12080642

Academic Editor: Christina M. Gschwandtner

Received: 17 July 2021

Accepted: 9 August 2021

Published: 13 August 2021

Publisher's Note: MDPI stays neutral with regard to jurisdictional claims in published maps and institutional affiliations.

Copyright: (C) 2021 by the author. Licensee MDPI, Basel, Switzerland. This article is an open access article distributed under the terms and conditions of the Creative Commons Attribution (CC BY) license (https:/ / creativecommons.org/licenses/by/ $4.0 /)$.
Georgetown University Jesuit Community, Washington, DC 20007, USA; wwoody@jesuits.org

\begin{abstract}
Phenomenology holds great promise yet underdeveloped potential for ritual studies and liturgical theology. As phenomenology has indeed taken a "theological turn" and the contentiousness of such an approach abates, questions remain as to what insights, concepts, and language phenomenology can offer to deepen our understanding of Christian ritual practices. Specifically with respect to rituals of initiation, does phenomenology open new avenues of appreciation for the sacrament of baptism, to enrich and to deepen the faithful's experience of these rituals? This article considers insights afforded by a phenomenological approach to the sacrament, in particular with regard to adult baptism and the catechumenate in the Rite of Christian Initiation for Adults (RCIA), the rite of reception and sacramental initiation into the Roman Catholic Church. Considered through such lenses, a phenomenology of baptism promises to open new avenues of ritual understanding, theological appreciation, and depth of prayer. Drawing primarily from the work of Jean-Luc Marion, this article also considers prominent critiques of his work to articulate a phenomenology of baptism as an experience of givenness and reception, of identity formation within and through an ecclesial community, and of prayerful preparation for Christian neophytes.
\end{abstract}

Keywords: liturgical theology; initiation; phenomenology; baptism; ritual studies; RCIA

\section{Introduction}

Contemporary trends in phenomenology have given rise to a whole host of new language, concepts, and perspectives that enable us to appreciate better and to articulate more meaningfully ordinary human experiences. Yet beyond the scope of the ordinary and the mundane, the promise of such inquiries to plumb the riches of sacramental experience remains to be investigated. Indeed, recent works in phenomenology have given rise to potentially enlightening perspectives on more extraordinary experiences of a religious nature. Thinkers accused of the "theological turn" in phenomenology have drastically expanded the scope of phenomenological inquiry, providing both concepts and language through which to approach religious experience in a novel and remarkable way (Janicaud 2000; Marion 2002b, 2008a). Nonetheless, while phenomenology holds great promise as a method for liturgical theology and ritual studies, a shocking dearth of engagement persists, despite a few notable exceptions. ${ }^{1}$

In the spirit of such philosophical works and innovations, this paper proposes that a phenomenological assessment of sacramental initiation (specifically of the Rite of Christian Initiation for Adults through baptism) may enrich our perspective on this foundational Christian sacrament, and open new avenues for theological inquiry. Such an assessment provides a rich case study for a sacramental rite that many Catholics may have witnessed, received, or even administered during the Easter Vigil, though it is by no means the exclusive example of sacramental initiation open to phenomenological analysis. Maintaining both the value of a phenomenological approach to theology as well as the validity of the "theological" within the scope of phenomenology itself, this paper argues that a properly theological phenomenology can emerge when deployed in the assessment of the sacramental theology and ritual practices of a faith community. In adopting such a reading, this 
paper hopes to bring into relief certain characteristics of ritual, sacramental practices which, while not entirely unnoticeable, might otherwise recede into the background and evade more explicit consideration.

Phenomenology provides a useful lens to supplement liturgical theology and ritual studies in this endeavor. A phenomenological approach brackets questions of causality and liberates our inquiry from the constraints of traditional metaphysics, instead preferring to focus on the direct description of experience. This is not to dismiss entirely larger metaphysical concerns and questions. Rather, by bracketing them, the focus of our inquiry can be sharpened to the direct description of phenomenological experience, which brings into relief otherwise unexamined (or unperceived) avenues of inquiry.

Drawing primarily from the work of Jean-Luc Marion and supplemented by more recent critiques of his work, the initial section of this paper fleshes out key concepts of Marion's phenomenology-in particular, those of saturation, givenness, and identity reception. ${ }^{2}$ Chastened by his numerous critics from a more hermeneutic approach, this paper then proceeds to identify three characteristics that come into focus when using a phenomenological lens for the assessment of Christian sacramental experience: the inexhaustible meaning of the sacrament as a saturated phenomenon; the primacy of receptivity from the wider community in identity formation over individualistic selfdetermination; and the centrality of context and preparation (catechesis) in the reception of sacramental phenomenon. Such a reading will prove fruitful in sharpening our focus on essential characteristics of otherwise disparate baptismal practices and motifs in the Christian sacramental imagination.

\section{The Primacy of Givenness: Theological Turnings in Marion's Phenomenology}

Further cementing the fiercely contested shift toward transcendence in contemporary phenomenology, Jean-Luc Marion paves the way for phenomenological assessments of explicitly religious and theological matters—notably Revelation and sacramentality. Marion departs from Husserl's phenomenological horizons and dispenses with Heidegger's Dasein in order to break free from egocentric subjectivity in favor of the transcendence of a phenomenon's essential givenness. Emphasizing the way a phenomenon gives itself over and above the subject's ability to constitute or to limit its particular mode of manifestation, Marion reverses the primary emphasis from the subject to the phenomenon itself-a move that becomes all the more clear in his discussion of "the saturated phenomenon". Further exposition of what such "saturation" entails and what exactly Marion means by the primacy of givenness will prove necessary before assessing its wider implications for epistemology, subjectivity, and self-identity.

\subsection{Saturation and Manifestation}

Marion's sketch of the saturated phenomenon and the preeminence of givenness derives from his reinterpretation of German phenomenology through Kantian categories and in the wake of Levinas's critiques. ${ }^{3}$ As a phenomenologist, Marion's primary goal is to allow the "things in themselves" to appear, though both the constituting subject of Kant and the intentional horizons of Husserl place implicit limits and conditions upon the appearance of the "things in themselves" as phenomena (Marion 2002a, pp. 196-97; Marion 2008b, p. 31). For Kant, the apperception of objects is organized by the structures of reason in the mind of the subject, whereby the subject "constitutes" objects through the imposition of categories and according to space and time. Husserl's innovation through the transcendental reduction and the bracketing of the natural attitude of the subject likewise asserts a strong subjectivity, constituting objects through intentionality and the structures of consciousness. Even Heidegger's phenomenology, characterized by the opening of a world through Dasein rather than an objectifying subjectivity, depends too heavily on a first-person perspective grounded in a subject (Marion 2002c, p. 133). Nonetheless, Marion employs the language and framework set forward by such German influences in order to flesh out his idea of a saturated phenomenon and recast contemporary phenomenology. 
Marion turns to the Kantian categories of understanding (quantity, quality, relation, modality), alongside Husserl's ideas concerning intuition/intentionality, and "overwhelms" them with the excessive and uncontainable givenness of the phenomena-what Marion comes to term "saturation" with intuition (Marion 2008b, pp. 18-48). Intentionality is reversed and priority is no longer ascribed to the subject constituting the world, but rather to the phenomenon which gives itself as this overflowing, superabundant givenness that exceeds any intentional adequation or conceptual schematization.

The conceptual framework provided by our mental categories can thus only capture a small portion of this excessive intuition that is given by the phenomenon-the "overflowing" of intuition prevents one from neatly adequating it with concepts (Kant) or intention (Husserl). Marion describes four types of saturated phenomena which "exceeds the categories and principles of understanding - it will therefore be "invisable" [unable to be intended/aimed at] according to quantity, unbearable according to quality, absolute according to relation, and incapable of being looked at according to modality" (Marion 2008b, p. 34). To offer more concrete examples of each, Marion points to historical events (saturated in quantity), artwork (saturated in quality), fleshly experience of the lived body (saturated in relation), and the encounter with alterity, the face of the human other (saturated in modality), as well as the possibility of a saturated phenomenon par excellence, one which encompasses all four possible means of saturation-divine revelation. ${ }^{4}$ For example, any phenomenological study of artwork "saturated in quality" will never succeed in capturing its meaning perfectly. The intuition of the phenomenon will always overflow and exceed my concepts-thus I cannot ever say that I "understand" or "know" the painting because some intuition always remains beyond my ability to conceptualize. Further, this saturation does not simply imply a lack of understanding or epistemological representation; the excessive intuition may evade being made manifest in any perceptual way at all-its saturation might be so overwhelming, so bedazzling that it never appears to me in the first place. Thinking of the "self" as a screen onto which a saturated phenomenon is projected (as light), the beam of light would exceed the limits of the screen in this instance-allowing certain aspects of what is projected to appear while nonetheless overflowing the boundaries of the screen which cannot hold the projection in its entirety.

In an absolute rejection of the subjectivity whose thought both constitutes and conceptualizes the phenomenal world, Marion's "self" arises as the recipient-the one who receives a given phenomenon which precedes and exceeds the self (whom Marion comes to call l'adonné, or the gifted).

Before turning to a more sustained investigation of the role that a phenomenon plays in creating or giving rise to this identity of the self, this paper would be remiss not to underscore further the centrality that saturation plays in Marion's thought as a whole. The excessiveness of givenness, the superabundance of intuition, and its ultimate inability to be contained by any concept renders these phenomena necessarily multivalent, inexhaustible, and unable to be grasped perfectly.

Marion places the initiative and primacy on the phenomena themselves, and his principle of phenomenology serves to "give priority back to the phenomenon ... The $I$ is made the clerk, the recipient, or the patient of this process, but almost never the author or the producer. In this way, the metaphysical and subjective figure of transcendentality undergoes a reversal" (Marion 2002b, p. 26). Thus, the givenness of phenomena retains primacy for Marion - over and above the role of the self, givenness holds priority and occurs anterior to the manifestation of a phenomenon (or, in more technical terms, the givenness of a phenomenon precedes and exceeds its entrance into the subjective horizon of phenomenality). Marion distinguishes originary givenness from phenomenality/manifestation and prioritizes the givenness over the manifestation. He notes, "all phenomena appear, but only to the extent that they show themselves ... a phenomenon only shows itself to the extent that it first gives itself" (Marion 2002b, p. 30). Here, Marion underscores the primacy of givenness, though he consistently rejects that the opposite is true, "All that which gives itself does not show itself necessarily—givenness is not always phenomenal- 
ized" (Marion 2002b, p. 30). Marion thus effects a reversal of the relationship between appearing phenomena and the self, rendering the self a necessary condition for the phenomenality/manifestation of givenness, while nonetheless having no constitutive power over givenness itself. ${ }^{5}$

This emphasis on the givenness of the phenomenon over the constitutive power of the subjective self clearly marks a great chasm between his thought and previous modes of thinking subjectivity. Marion's notion of saturated phenomena forms the cornerstone of his entire phenomenological project—establishing the priority of givenness over the subject and the means through which Marion articulates a new vision of the self as "the gifted", as l'adonné.

\subsection{L'Adonné and the "Gifted" Self: Identity as Reception}

In addition to the centrality of saturated phenomena and its potential value in reading accounts of early Christian initiation practices, Marion's account of the self in relation to these phenomena will also prove helpful when considering ritual initiation as identity formation. This paper now turns to consider Marion's account of selfhood and identity in the face of these "saturated" phenomena-a selfhood that persists even as modern subjectivity is displaced.

In lieu of the constituting subjectivity of modernity (characteristic of both Descartes and Kant, but also of Husserl according to Marion), a new form of the self arises in this form of l'adonné. Marion's account of the saturated phenomenon gives particular attention to this claim:

The $I$ loses its anteriority and finds itself, so to speak, deprived of the duties of constitution, and is thus itself constituted: it becomes a me rather than an $I \ldots$ When the I finds itself constituted by a saturated phenomenon, it can identify itself as such only by admitting the presence of such a phenomenon over itself.

(Marion 2008b, p. 44)

The constituting " $I$ " of the modern subject thus finds itself displaced and its powers of constitution reversed by an encounter with this anterior givenness. Although a privileged insight derived from a phenomenological approach, Marion nonetheless criticizes other phenomenologists of losing sight of this originary givenness and reinscribing it into subjectivity. Most notably, he takes aim at Husserl as falling too far into the modernist camp that still asserts a constituting and strong subjective self. Even in the wake of Husserl's initial phenomenological reduction, Marion warns, "metaphysical egology is a paradigm that always haunts the I, even reduced, even phenomenological" (Marion 2002a, p. 187). His phenomenology reacts strongly against the subjective, constituting self of modernity, rejecting any vestige of a subject who dominantly imposes, projects, or constitutes the world as object. In the experience of the saturated phenomenon, the self realizes that "the excess of intuition could no longer satisfy the conditions of ordinary experience and that the pure event that occurs cannot be constituted as an object and leaves the durable trace of its opening only in the I/me that finds itself, almost in spite of itself, constituted by what it receives" (Marion 2008b, p. 44). The self thus emerges only in reference to and as received from the givenness of phenomena. Or rather, to demonstrate in more grammatical terms, Marion articulates the existence of a self neither in the nominative case of strong subjectivity nor in the accusative case of objective passivity, but rather in the dative case of reception - the indirect object to whom givenness is directed and given. ${ }^{6}$

In sum, Marion's phenomenological prizing of givenness as primary and anterior to all else enables him to recast the self as a subject without or beyond subjectivity. ${ }^{7}$ As l'adonné-the "gifted" who is addressed, given to, and receptive- the arising of the self occurs only as a consequence of this primary givenness on the part of the phenomenon. Marion thus enacts a complete reversal of the modern subject—an approach, as we shall see, that is not without its problems or criticisms. 


\subsection{Hermeneutic Grounding of Receptivity—Contemporary Critiques of the Gifted Self}

Rather than embrace without question the structure put forward by Marion in his initial articulations of his "phenomenology of givenness", this paper turns briefly to consider a recurring objection against such a view of the self. Current critiques and scholarly debates attempt to emphasize or "reclaim" the role of hermeneutics in phenomenology-the contextual grounding of the self and the lens through which it "receives" such phenomena. While Marion leaves almost no room for hermeneutic grounding or interpretation in his version of phenomenology, this paper suggests that a less extreme version-tempered by these critiques yet preserving its fundamental framework - provides a necessary corrective to Marion's otherwise absolutist and extreme account.

Recent scholarship has taken aim at the perceived lack of freedom, activity, and initiative on the part of this new self (l'adonné) a "subject beyond subjectivity" which no longer constitutes the objects of perception (as in Kantian thought). Although Marion's rejection of modern subjectivity is, in itself, not problematic or questionable for these critics, the manner in which he does so brings about some unpalatable consequences by eliminating any attempt to prepare for, anticipate, or hermeneutically ground the reception of phenomena. For many critics, this lack of hermeneutics renders the gifted self too passive in its reception of phenomena. Yet this critique is two-fold, not merely a debate between the activity or passivity of the subject, but at stake is the very understanding of the self. By displacing hermeneutics or attention to the situation of the self, Marion seemingly advocates a "naïve" understanding of the self, removed from its situation, its history, its embeddedness within a world. ${ }^{8}$ Or, as Kevin Hart helpfully observes, Marion's project disengages phenomenology from hermeneutics "at their undermost level of contact as determined by Heidegger, that of fore-having (Vorhabe), fore-conception (Vorgriff) and fore-sight (Vorsicht), and reattaching hermeneutics to phenomenology only once the phenomenon has been received" (Hart 2013, p.4). Attention to the hermeneutic grounding, the situation, and the history that have shaped the self become an afterthought, and the role of interpretation is relegated to a post-facto activity irrespective of the self's unique situation. While Marion has reversed the constituting subject of modernity, the consequences of this move have seemingly relegated hermeneutics to an inferior, incidental, and unimportant role. ${ }^{9}$

Marion's lack of hermeneutics does not simply pose a theoretical problem but has severe consequences for any epistemology or ethical theory that stems from his project. Condemning the self to such extreme passivity and failing to take into account its particular context or situation in the world, the individual serves as nothing more than an empty screen onto which phenomena are projected (Marion 2002a, p. 265). It thus appears that, according to Marion's account, one would have no responsibility to cultivate their abilities or expand their capacity to receive phenomena-one is nothing more than an empty screen, idly waiting for phenomena to "project" themselves onto them. Not only would one be exonerated from any responsibility to cultivate or consider their situation, one would remain incapable of doing so in the face of an utterly overwhelming, unanticipated and truly excessive arrival ("eruption") of the saturated phenomenon. If we are to consider artwork, history, human relationships, and God as examples of saturated phenomena, then surely we must be called to enlarge our capacity to appreciate, or to deepen our awareness, of these phenomena. The possibility for depth of understanding, appreciation, and even creativity collapse as Marion's passive "adonné" can do nothing to prepare for the phenomenon-it merely stands ready to receive the givenness projected from beyond. Further, by refusing to allow for a hermeneutic grounding to phenomena, Marion fails to consider the differences in perspective across culture, era, gender, or race, and seemingly whitewashes any diversity by rendering every individual an equally blank screen. The gifted self of Marion is stripped not only of its agency, but of its history as well.

Foremost among Marion's critics on this front is Shane Mackinlay, who objects that Marion relegates any hermeneutic element or activity on the part of the self to a mere "series of epistemic acts that interpret the meaning of a phenomenon after it has already appeared. The actual appearing of the phenomenon is fully accomplished independently 
of any such interpretations of its meaning" (Mackinlay 2007, p. 50). Contrary to this conception, Mackinlay points to the more Heideggerian notion of hermeneutically-grounded phenomenology in which human existence and experience "is itself considered to be hermeneutic in the very structure of its happening", thus rendering phenomena as, to some degree, always already interpreted as they appear (Mackinlay 2007, p. 50). Mackinlay continually reiterates this call for a reclamation of hermeneutics as the founding disposition or act that grounds the reception of the givenness of phenomena on the part of the gifted/l'adonné.

This ignorance (or rejection) of hermeneutics is a critical flaw in Marion's phenomenology. The new paradigm for phenomenology offered by the theory of the saturated phenomenon is not, as Marion asserts, one "in which phenomena give themselves and show themselves on the basis of some pure and absolute givenness", but rather relies upon the clearing of a "hermeneutic space that is opened by the one who receives them. Going back 'to the things themselves' cannot be achieved by leaving hermeneutics behind" (Mackinlay 2010, p. 220). Mackinlay asserts the need to shift away from Marion's extreme position of absolutizing the givenness of phenomena while simultaneously resisting the temptation to return to the opposite pole, a strongly constituting subjectivity. Mackinlay thus advocates a more qualified, middle-ground position:

The appearing of phenomena is better understood as a middle-voiced happening.

The choice of a middle voice means that neither phenomena nor the recipient are described in terms that are exclusively active or passive. It reflects the essential interrelatedness of phenomena, the subject to whom they appear, and the world in which the event of that appearing occurs. This interrelatedness is hermeneutic not only in the sense that phenomena receive an epistemic interpretation subsequent to their appearance, but also in the ontological sense that interpretation is a fundamental part of the appearance's structure. (Mackinlay 2010, p. 219)

For Mackinlay, then, the reclamation of hermeneutics as a "fundamental part of the appearance's structure" does not herald a return to the constituting subject of modernity, yet it overcomes the concern that Marion's gifted self fails to account for its particular context and grounding, as well as falls too drastically into a passive position without any responsibility on the self's part (Mackinlay 2005, p. 167). ${ }^{10}$ Despite Marion's repeated responses that his work is beyond the simple dichotomy of "activity" versus "passivity" (neither nominative nor accusative, but a dative subject), an ambiguous relationship persists between the two and-in Mackinlay's view-Marion resolves this tension almost always in favor of passivity. This very concept of a self as "l'adonné" only arises in the experience of a phenomenon, for "only the impact of what gives itself brings about the arising [of the gifted], with one and the same shock, of the flash with which its first visibility bursts and the very screen on which it crashes" (Marion 2002a, p. 265). According to these readings, Marion's self serves no other purpose than to be the screen onto which these phenomena are projected. ${ }^{11}$

Yet despite protestations on Marion's part against the illegitimacy of this avenue of critique, other commentators have similarly highlighted the ambiguity of the passive/active opposition latent throughout Marion's work or criticized his lack of hermeneutic grounding for the self (Kearney 2005; Gschwandtner 2014; Serban 2012; Schrijvers 2006). Such critiques all seek to temper Marion's more radical emphasis on the primacy of the givenness of phenomena by reclaiming the context, capacities, and role of the self beyond mere reception. ${ }^{12}$

These critics all advocate some reclamation of a role for the self-either a consideration of the self's context and capacities in the face of these overwhelmingly saturated phenomena, or a reclamation of activity on the part of the self. Marion's account creates problems in his desire to emphasize the priority of the phenomena over the self-by offering so absolute and extreme a corrective against prevailing notions of subjectivity, he goes too far in forgetting the context and capacities of the self. The problem with the lack of a hermeneutically-grounded self is the lack of responsibility to cultivate one's capacities to re- 
ceive phenomena, an inability to deepen our appreciation, understanding, and knowledge of said phenomena, and a forgetting of the creative potential of the human mind.

Continued scholarly critiques in both Franco- and Anglophone circles highlight the ambiguous and problematic nature of Marion's gifted self "beyond" or "without" subjectivity-both in its lack of hermeneutic grounding and its apparent denigration to a stance of passivity. Yet it is in the wake of these recent critiques that a more moderate, tempered version of Marion's phenomenology emerges-one that maintains the primacy of givenness and phenomena while nonetheless reasserting the necessity of hermeneutic grounding and contextualization, the potential for preparation for reception of phenomena, and a more pronounced role for the self.

\section{Sacramental Initiation as Saturated Phenomenon}

Having sketched out the major characteristics of a phenomenological framework, I now propose adopting its vantage point for a more theological phenomenological perspective on the sacramental experience of baptism. I shall follow an outline according to three themes sketched above - the inexhaustibility of saturated phenomena, the primacy of givenness in the reception of self-identity, and the necessity of hermeneutic grounding and preparation.

\subsection{Multivalent Meanings, Inexhaustible Phenomena}

Marion would classify a sacramental experience as a prime example of a saturated phenomenon, and using his phenomenological account we can glean an underlying sense of the unity of the baptismal "phenomenon" despite its varied depictions and understandings throughout the history of Christianity. Marion's articulation of a saturated phenomenon preserves the integrity of a singular phenomenon while nonetheless allowing for an essential polysemy or originary multivalency when it enters into a horizon of phenomenality-a horizon that can never express fully or capture definitively the givenness of phenomena in an exhaustive way.

A review of early Christian understandings of baptism-through catechetical writings, depictions in artwork, texts describing ritual practices, and the more spiritualizing/metaphorical readings of baptism-reveals a wide array of competing and varied understandings. Yet considered as a saturated phenomenon, such polysemy or multivalency would only prove appropriate and necessary-attempts to convey the inexhaustible nature of its givenness in otherwise limited modes of manifestation. A singular image or motif could capture a particular aspect of the practice, offering an internally coherent depiction that sums up the meaning of baptism but which by no means proves exhausting or fully comprehending the meaning of the sacrament. The experience cannot be entirely captured by human concepts or images-and thus recourse to multiple, sometimes competing motifs emerges. Similarly, not only motifs and descriptions but the meanings associated with the ritual actions themselves take on a polysemic and inexhaustible dimension. ${ }^{13}$

Much like our mental schema and concepts in the face of saturated phenomena, the depictions and understandings of baptism can never fully capture or exhaust the significance of the ritual. The numerous, disparate understandings of initiation convey not contradictory or competing theologies per se, but rather speak to the inexhaustibility of that which is experienced and which the community of believers seeks to express in meaningful terms. ${ }^{14}$

Throughout the early Christian world, many different images and practices prevailed: birth mysticism grounded in John 3 and its emphasis on being "born anew" arose in some depictions, while the death mysticism from Romans 6 later held primacy in the fourth century. Beyond the fairly consistent image of the Christian community as a family ("brothers and sisters" united under God the Father) baptism also came to hold associations with nuptial imagery and wedding banquets, illumination, washing and forgiveness, recreation and resurrection, as well as a sealing, branding and, in some cases, military enlistment. Despite seeming incommensurability, these images were not mutually exclusive 
of one another-and indeed many authors juxtapose strikingly different motifs in order to convey the richness and inexhaustibility of meaning. Cyril of Jerusalem, for example, draws simultaneously from many different tropes in his Catechetical Lectures on baptism. He links the stripping of one's tunic with both the nuptial union celebrated as "the Spouse of Christ in the Song of Songs", while nonetheless connecting such nudity with a sharing in Christ's passion, "stripped naked on the Cross" (Cyril of Jerusalem 2014, pp. 657-64). Others similarly draw from multiple images simultaneously. John Chrysostom appeals to the essential polysemy of the sacrament in his Baptismal Instructions: "To call what takes place today a marriage would be no blunder, not only could we call it a marriage, but even a marvelous and most unusual kind of military enlistment", he begins, noting that he would speak to the initiate as a bride about to be led into the nuptial chamber-one who is also about to receive forgiveness by escaping from her "sordid past" (Chrysostom 1962, pp. 23-42). Marriage, military enlistment and forgiveness stand alongside one another as equally valid modes of understanding the sacrament, yet without contradicting one another nor fully capturing the exhaustive meaning of the baptism.

\subsection{Identity Reception and Communal Identity}

In addition to the variable depictions and the inexhaustibility of expression latent within saturated phenomena such as sacramental initiation, another critical point comes into relief when read in the light of Marion's phenomenology. The reception of this phenomena bears upon the very identity of the individual in question - an identity and a selfhood that is truly gifted, or even graced. One's identity is received through an encounter with this phenomenon, not one that the individual can construct or attain on one's own.

Marion's identification of the self as l'adonné places primary emphasis on the process of reception in the arising of a self and in the constitution of one's identity. Certain images (such as nuptial union, military tattooing, or livestock branding) and the ritual practice itself incarnate this sense of receiving one's identity from the rite of initiation. The initiate receives his or her self and identity from that which precedes and exceeds him or her: from the Christian community as a whole, from the ritual practice that is performed by another, from a tradition that far exceeds his or her own history, and from transcendent Divinity. The act of reception in this sacramental encounter conveys a new identity in which the "self" is defined by that which it receives. Indeed, the priority of the community or of the Church (the "Ecclesial We", as Chauvet describes), is manifest not only in the ritual itself but in its consequences- that one is enabled to join in the communal meal, to be numbered amongst the faithful, to take on the collective name of "Christian" through a sacramental initiation that is received from without (Chauvet 2001, pp. 31-32; Marion 2017, pp. 47-48; De Lubac 1988, pp. 82-83; McGowan 2014, p. 152). None of these are attained through one's own merits or undertaken by one's self-determination. They are bestowed and received from the community, the priest/minister, and from God.

The recurring image of nuptial union captures this "reception of identity" in both cultural and theological terms. The aforementioned accounts which appeal to nuptial union depict the initiate as a "bride of Christ", and that Christ himself is the bridegroom. Theologically, nuptial union conveys a new identity as the "two become one flesh", 15 and for the bride this took on a very practical and noticeable reception of a new identityleaving the household of her father upon being taken into the household of her bridegroom.

In a similar way, certain ritual practices conveyed a sense of the reception of identity or notion of belonging - appealing to the imagery of sealing, stamping, branding and tattooing of soldiers in a legion or livestock in a flock. Peppard draws from the writings of Theodore of Mopsuestia, explaining the "sealing" conveyed through the ritual of anointing as a sign of being "stamped as a lamb of Christ and as a soldier of the heavenly King" (Peppard 2016, p. 94). Such practices of sealing or tattooing bestowed clear identity and a sense of belonging, even of ownership or mastery-designating to whom the soldier renders his service and loyalty, or signifying ownership over the livestock. It is a reality and a hope expressed every Sunday in Night Prayer (Compline), declaring that those united to 
Christ "shall see the Lord face to face and bear his name on their foreheads" (Rev. 22:4). Baptism confers an identity, indelibly, by which the faithful are bound to Christ as his own.

Such emphasis on reception of identity from the phenomenon in question (sacramental baptism) also manifests itself in practical details attested to by the Christian communities. Notably, one cannot convey baptism upon oneself or "auto-baptize" — it must be received from another, in the proper setting, and takes place in a communal liturgical event. Indeed, the Christian community understood a real, fundamental change to have taken place in the reception of the sacrament. Such an act of reception cannot be conveyed or accomplished in an act of self-administration - this phenomenon of baptism and the identity it conveyed upon the initiate (l'adonné) were necessarily received from elsewhere: theologically from the Divine, practically from the community, and efficiently through a ritual performed upon the initiate by a presider. ${ }^{16}$

Further underlining this notion of "reception" from a very particular, sacramental source is the way in which the Christian community sought to dispense with other markers of identity differentiation. Christians understood themselves (at least in the most idealized accounts) to have received a new identity independent of the wider cultural, secular means of identity formation. As such, one should not appeal to distinctions of identity conveyed from worldly sources. Ultimately, this newfound Christian identity derived purely from Christ in the reception of baptism. Gregory of Nazianzus's practical exhortation in his Festal Orations on baptism capture this sense quite explicitly, urging the faithful to put aside worldly distinctions and identities in favor of a new transformation-one which is commonly shared by the faithful in Christ:

Do not disdain to be baptized with a poor person if you are rich, with one lowly born if you are noble, with one up to now a slave if you are a master. You are not yet humbling yourself as much as Christ, into whom you are baptized today, who for your sake even accepted 'the form of a slave.' From the day you are transformed, all the old imprints have withdrawn; Christ has placed himself upon all as a single form. (Gregory of Nazianzus 2008, pp. 122-23)

Through baptism, as Gregory exhorts, a new form or imprint is bestowed upon the initiate, displacing his or her previous markers of identity and universalizing a commonlyreceived identity shared amongst members of the Christian community. Accounts from both within the Christian community as well as external critics similarly promote this perspective, present in both the writings of Paul and the lamentations of Pliny. Paul famously declares, "There is no longer Jew or Greek, there is no longer slave or free, there is no longer male and female; for all of you are one in Christ Jesus" (Gal. 3:28), an observation made apparent even in the external (and highly critical) assessment of Pliny in his letters to the emperor regarding the earliest Christians (Pliny 1969, pp. 289-91). Both Paul and Pliny attest to the belief that Christians no longer derived their identity or differentiation from secular sources such as social standing, race, or gender. In Christ, all have received a new and equal identity through the process of such initiation. Christian initiation rituals thus - in their most idealized form-resist other modes of identity differentiation and articulate their own understanding of identity reception/formation through a sacramental (saturated) phenomenon.

\subsection{Preparation and Catechesis: The Hermeneutic Grounding of the Subject}

Critical attempts at recasting Marion's phenomenological framework similarly have relevance to our consideration of early Christian initiation and identity reception. In the wake of scholarly critiques and appeals for Marion to reconsider the situation of the recipient, our attention turns from the act of reception to that which renders it possible: ritual acts of preparation, instruction, and prayer. For Christian initiates (catechumens), the central importance of preparation and contextualization cannot be ignored in the sacramental experience of baptism. A level of hermeneutic grounding-accounting for the recipient's disposition, situation, and level of preparation-renders the reception of the phenomenon possible in the first place. 
While our primary concern here is to consider sacramental initiation of adult catechumens, the widespread practice of infant baptism raises questions about such a hermeneutic grounding. Questions of preparation, reciprocation, and formation are not entirely absent in this regard - though they are displaced by proxy. The necessity of sponsors-godparents or witnesses-and the role of ongoing catechesis or formation arise in this regard. Importantly, the preparation and willingness of such sponsors is critical, and many churches that practice infant baptism offer "Pre-Jordan" programs for the catechetical instruction, formation, and preparation of godparents and sponsors in this regard.

Ritual practices placed high value upon such a disposition, situation, and preparation. Consequently, the role of instruction and catechesis during an extended period of time proved essential to render the individual capable of baptism. In addition to instruction of the mind, embodied practices of penance and preparation took place in the form of fasting, and spiritual preparation through prayer preceded initiation. Accompaniment by those already initiated into the faith as sponsors became a requisite practice. Days of recollection and prayer, retreats and spiritual direction, ongoing catechetical instruction, and even sacramental confession have been encouraged as preparatory practices to dispose oneself to receive the sacrament of baptism. ${ }^{17}$ The sacramental grace was not convoked out of thin air or imposed without adequate preparation; the seed must not fall upon the path, or rocky ground, or among thorns but upon rich soil, fertile ground to produce good fruit (Matt. 13:4-8). These acts of preparation and instruction render possible the reception of the sacramental phenomenon, the reception of its originary givenness, and ultimately the reception of one's Christian identity.

\section{Conclusions}

Granted, far more connections can be drawn between other primary texts and Marion's phenomenological framework, and undoubtedly other vantage points from a phenomenological perspective exist - though a more sustained and exhaustive examination exceeds the scope of this brief sketch. I endeavor here solely to provide an initial reading of Christian ritual practice through the lens of contemporary phenomenology-positing the value and insight that such a reading may offer in the field of theology, ritual studies, and examinations of sacramental initiation.

Marion's phenomenology and his emphasis on the primacy of givenness yield a rich and insightful means through which to reconsider the sacramental practice of Christian initiation. His analyses of saturated phenomena, identity formation, and reception of selfhood offer new language and valuable ideas to frame further examinations in a genuinely theological phenomenology. While by no means exhaustive or holding an exclusive purview, the lens of contemporary phenomenological frameworks can bring into focus certain characteristics, qualities, and underlying commonalities that otherwise escape notice or assessment. It is in this way-as a conceptual resource and potential tool for theology - that I contend contemporary phenomenology offers an underutilized yet richly insightful means of approaching topics of theological inquiry and ritual studies, of both transcendent religious experience and liturgical human practice.

Funding: This research received no external funding.

Institutional Review Board Statement: Not applicable.

Informed Consent Statement: Not applicable.

Data Availability Statement: Not applicable.

Conflicts of Interest: The author declares no conflict of interest.

\section{Notes}

Marion notes the preference for historical, hermeneutic, or semiotic methods over phenomenological readings in theology. While he nonetheless does identify Hans Urs von Balthasar as a notable exception in this regard, Marion criticizes the general exclusion of phenomenology from theological endeavors (Marion 2002b, p. 29). Recent years have seen a number of notable developments 
in this regard which have embraced phenomenology as a method appropriate to liturgical practices and rituals (Gschwandtner 2019; Falque 2012).

2 While Marion does not explicitly identity baptism or initiation rites as examples of saturated phenomena, he certainly privileges the sacrament of the Eucharist as the saturated phenomenon par excellence, revealing the theological underpinnings to his project while nonetheless retaining its primarily phenomenological (rather than theological) character (Marion 2008a, pp. 98-99).

3 For a more critical assessment of Marion's work, see the objections put forward by Dominique Janicaud against the entrance of transcendence into phenomenology and his cautions against the hijacking of phenomenology by a theological turn (Janicaud 2000, pp. 16-103). Janicaud rejects the purely phenomenological nature of Marion's project by claiming that his work takes methodological liberties (à la Levinas) into the realm of transcendence, while simultaneously amalgamating the "Cartesian" and "Kantian" projects with the "different undertaking" of Husserlian reduction (Janicaud 2000, p. 56). A less polemically charged critique is offered by Shane Mackinlay, noting, "Marion's argument depends upon taking key Husserlian terms ('intention', 'intuition', 'signification', 'adequation') and interpreting them in the context of Kant's understanding of the relation between intuition and concepts” (Mackinlay 2010, p. 74).

4 Marion initially proposes these distinctions in the final two books of Being Given (Marion 2002a), although he does not return to flesh them out further until the later publication of In Excess: Studies of Saturated Phenomena (Marion 2002b). It is also here in this later work that Marion explicitly asserts the value of this idea of a "saturated phenomenon" beyond purely philosophical accounts. He especially highlights the potential value of his contributions for applications to historical inquiry and theology, and laments the exclusion of phenomenological inquiry from theology to the detiment of both (Marion 2002b, pp. 27-29).

5 Marion famously sums up this relationship between the self (l'adonné/the gifted) and the givenness of phenomena as "the sole master and servant of the given" (Marion 2002a, p. 319).

6 Elsewhere Marion identifies this movement as one away from the "nominative" active self of modernity (as subject) as well a rejection of the "accusative" passive self (of Levinas). Instead, he characterizes his movement of subjectivity toward something of a "dative" self-one of reception. He compares his idea of self with both modern and contemporary versions of selfhood and subjectivity, writing, "the ego is not itself therefore by itself-neither by self-apprehension in self-consciousness (Descartes) nor by a performative (Descartes), nor by apperception (Kant), nor even by auto-affection (Henry) or anticipatory resoluteness (Heidegger). The ego does not even accede to itself for an other (Levinas) or as an other (Ricoeur); rather, it becomes itself only by an other-in other words by a gift; for everything happens, without exception, as and by a gift" (Marion 2012, p. 285).

7 Gschwandtner offers a helpful account on this point: "The 'subject without subjectivity' is not only convoked and addressed, but it suffers a surprise that dislocates any attempt to constitute itself as a subject", and further, "to accept the gift is to be displaced in one's subjectivity, to be challenged in one's constitution as a subject... to receive the gift in the attraction and prestige of its phenomenality is to sacrifice one's autarchy and to be dislocated by the decision of acceptance. Indebtedness ... plays an essential role for Marion since it assures the realization of the lack of autarchy in the subject and makes the self dependent upon something or someone prior to it" (Gschwandtner 2007, p. 209).

8 I am grateful for the feedback provided during the review process highlighting the two-fold nature of this critique, and to tease out more clearly the distinct, albeit related, critique of the "dehistoricized" un-hermeneutically grounded self from the more common critique of an overly passive self.

9 Marion responds directly to these persistent critiques in a brief lecture series (Marion 2013, pp. 53-57). In response to critiques levied by Mackinlay (2010), Gschwandtner (2014), and Kearney (2005), Marion stresses that hermeneutics can only provide an a posteriori interpretation of phenomenality that have been made manifest already-not that our current context, situation, or grounding can have any bearing on the ability of these phenomena to appear in the first place.

10 Elsewhere, Mackinlay draws from the thought of Claude Romano as an example of a more hermeneutic phenomenology that critiques modern subjectivity "without limiting the subject to pure receptivity" as Marion does in his phenomenology of givenness. According to Mackinlay's reading, Marion eliminates the traces of a constituting subject "only by reducing the subject to a passive recipient on whom phenomena impose themselves" (Mackinlay 2005, p. 167). Subsequent chapters in this collection similarly highlight more hermeneutic critiques of Marion, notably by Richard Kearney (Kearney 2005, pp. 220-42).

11 Marion consistently challenges this characterization of his work along the lines of activity/passivity, a well-worn and persistent critique of his approach to phenomenology. As noted above Marion claims that the self is both "the sole master and servant of the given" (Marion 2002a, p. 319). Elsewhere he notes the inadequacy of the "active/passive" distinction as a misconceived objection (Marion 2008b, p. 174). He argues, "there is nothing like a simple choice between 'activity' and 'passivity', with no other option (these are, for that matter, only categories borrowed from Aristotle, radically metaphysical, whose phenomenological usefulness can be disputed). The [gifted] operates according to the call and response and manages the passage of what gives itself to what shows itself: neither the one nor the other corresponds to these categories. 'Passivity' and 'activity' intervene only once the characteristics of the [gifted] are misconstrued" (Marion 2008b, p. 174).

12 In addition to Mackinlay, several other responses criticize Marion along similar lines (Schrijvers 2006, p. 227). Claudia Serban similarly notes that the legacy of Marion's thought is the unfortunate rendering "null and void" the necessity of any recourse to hermeneutic thought (Serban 2012, pp. 81-100). Gschwandtner parses out these issues into separate critiques, arguing that while Marion does not slip into a dichotomy of activity/passivity in his account of l'adonné, his apparent lack of hermeneutics 
proves deeply problematic when considering the manner in which phenomena actually appear to a self who can "prepare" for or "anticipate" the arrival of certain phenomena (Gschwandtner 2014, pp. 14-24).

13 The meaning of the water, for example, could be associated with creation or death, with washing and atonement, or with tempering and strengthening (Ferguson 2009; Ratzinger 2007, pp. 15-18). The act of anointing or chrismation through oil similarly carries multiple significations in its uses without a singular, clear-cut, and fixed meaning (Winkler 1978, pp. 24-45).

14 Michael Peppard draws parallels between the sacramental imagination of the early Christian community and the postmodern condition of the present day. The polysemic worldview of postmodernity (phenomenology included) appears more commensurate with the ancient understanding than that of modern thought, which sought stable epistemological representations through fixed concepts. He notes, "the ideas of marriage, death, and birth are not as easily separated in the premodern worldview as they are for modern Western sensibilities. In almost all instances, marriages were precisely for the sake of giving birth, the wedding night was a consummating beginning of the process toward new birth, and pregnancy was for women fraught with the prospect of death for both mother and child. The polysemic stance of postmodernity-seeing marriage, death, and birth in one image-would not have been foreign to the late ancient viewer" (Peppard 2016, p. 210).

15 This motif of nuptial union conferring or even creating a new identity recurs frequently throughout scriptural accounts of marriage, notably Gen. 2:24; Mark 10:8; Eph. 5:31.

16 The curious (yet popular) example of Thecla stands as an exemplar on this point, for despite her apparent self-administered or "auto-baptism" in The Acts of Paul and Thecla, efforts were made to justify such an extraordinary act in its apparent illicit nature by appealing to her exceptional status-notably, her twice-attempted martyrdom, her unusual purity, asceticism and piety, and itinerancy (Schneemelcher 1992, p. 245). In more practical matters, the concern for the "official" reception of the sacrament was attested to from numerous sources. Church orders such as the Apostolic Tradition attest to the specific offices capable of performing baptisms. Tangible archaeological evidence also suggests a concern for maintaining a level of control over to whom and when such rituals could be performed, attested to by the fact that the baptistery door possessed a lock (Peppard 2016, p. 81).

Such practices persist to the present in Catholic Rite of Christian Initiation for Adults (RCIA) programs, which encourages a protracted catechumenate with catechetical instruction, days of prayer and retreats, even commends the practice of a sacramental confession prior to baptism. One of the more prominent historical examples comes from Justin Martyr who attests to the practice of fasting and prayer in advance of baptism for the neophytes (Justin Martyr 2014, p. 98).

\section{References}

Chauvet, Louis-Marie. 2001. The Sacraments: The Word of God at the Mercy of the Body. Translated by Madeleine Beaumont. Collegeville: Liturgical Press.

Chrysostom, John. 1962. The First Instruction. In St. John Chrysostom: Baptismal Instructions. Translated by Paul W. Harkins. Mahwah: Paulist Press, pp. 23-42.

Cyril of Jerusalem. 2014. Lecture XX: On the Mysteries of Baptism. In The Catechetical Lectures of St. Cyril of Jerusalem. Edited by Paul A. Böer. Edmund: Veritatis Splendor Publications, pp. 657-64.

De Lubac, Henri. 1988. Catholicism: Christ and the Common Destiny of Man. Translated by Lancelot C. Sheppard, and Sister Elizabeth Englund, OCD. San Francisco: Ignatius Press.

Falque, Emmanuel. 2012. The Metamorphosis of Finitude: An Essay on Birth and Resurrection. Translated by George Hughes. New York: Fordham University Press.

Ferguson, Everett. 2009. Baptism in the Early Church: History, Theology, and Liturgy in the First Five Centuries. Grand Rapids: Eerdmans. Gregory of Nazianzus. 2008. On Baptism. In Festal Orations. Translated by Nonna Verna Harrison. Yonkers: St. Vladimir's Seminary Press.

Gschwandtner, Christina M. 2007. Reading Jean-Luc Marion: Exceeding Metaphysics. Bloomington: Indiana University Press.

Gschwandtner, Christina M. 2014. Degrees of Givenness: On Saturation in Jean-Luc Marion. Bloomington: Indiana University Press.

Gschwandtner, Christina M. 2019. Welcoming Finitude: Toward a Phenomenology of Orthodox Liturgy. New York: Fordham University Press.

Hart, Kevin. 2013. Introduction. In Jean-Luc Marion: The Essential Writings. Edited by Kevin Hart. New York: Fordham University Press, pp. 1-38.

Janicaud, Dominique. 2000. Phenomenology and the 'Theological Turn': The French Debate. Translated by Bernard G. Prusak. New York: Fordham University Press.

Justin Martyr. 2014. First Apology LXI: Christian Baptism. In Writings of Justin Martyr. Edited by Paul A. Böer. Edmund: Veritatis Splendor Publications, p. 98.

Kearney, Richard. 2005. Hermeneutics of the Possible God. In Givenness and God: Questions of Jean-Luc Marion. Edited by Ian Leask and Eoin Cassidy. New York: Fordham University Press, pp. 220-42.

Mackinlay, Shane. 2005. Phenomenality in the Middle: Marion, Romano, and the Hermeneutics of the Event. In Givenness and God: Questions of Jean-Luc Marion. Edited by Ian Leask and Eoin Cassidy. New York: Fordham University Press, pp. 167-81.

Mackinlay, Shane. 2007. Exceeding Truth: Jean-Luc Marion's Saturated Phenomena. Pacifica: Australian Theological Studies 20: 40-51. [CrossRef] 
Mackinlay, Shane. 2010. Interpreting Excess: Jean-Luc Marion, Saturated Phenomena, and Hermeneutics. New York: Fordham University Press.

Marion, Jean-Luc. 2002a. Being Given: Toward a Phenomenology of Givenness. Translated by Jeffrey L. Kosky. Stanford: Stanford University Press.

Marion, Jean-Luc. 2002b. In Excess: Studies of Saturated Phenomena. Translated by Robyn Horner, and Vincent Berrand. New York: Fordham University Press.

Marion, Jean-Luc. 2002c. The Final Appeal of the Subject. In The Religious. Edited by John D. Caputo. Oxford: Blackwell.

Marion, Jean-Luc. 2008a. The Phenomenality of the Sacrament-Being and Givenness. In Words of Life: New Theological Turns in French Phenomenology. Edited by Bruce Ellis Benson and Norman Wirzba. New York: Fordham University Press, pp. 89-102.

Marion, Jean-Luc. 2008b. The Visible and the Revealed. Translated by Christina M. Gschwandtner. New York: Fordham University Press.

Marion, Jean-Luc. 2012. In the Self's Place: The Approach of Saint Augustine. Translated by Jeffrey L. Kosky. Stanford: Stanford University Press.

Marion, Jean-Luc. 2013. Givenness and Hermeneutics. Translated by Jean-Pierre Lafouge. Milwaukee: Marquette University Press.

Marion, Jean-Luc. 2017. On the Eminent Dignity of the Poor Baptized. In Believing in Order to See: On the Rationality of Revelation and the Irrationality of Some Believers. Translated by Christina M. Gschwandtner. New York: Fordham University Press, pp. 47-65.

McGowan, Andrew B. 2014. Ancient Christian Worship: Early Church Practices in Social, Historical, and Theological Perspective. Grand Rapids: Baker Academic.

Peppard, Michael. 2016. The World's Oldest Church: Bible, Art, and Ritual at Dura-Europos, Syria. New Haven: Yale University Press.

Pliny. 1969. Epistle 96. In The Letters of Pliny: Books VIII-X. Translated by Betty Radice. Cambridge: Harvard University Press, pp. 289-91.

Ratzinger, Joseph. 2007. Jesus of Nazareth: From the Baptism in the Jordan to the Transfiguration. Translated by Adrian J. Walker. New York: Doubleday.

Schneemelcher, Wilhelm. 1992. New Testament Apocrypha, Volume Two: Writings Relating to the Apostles; Apocalypses and Related Subjects. Translated by R. McL Wilson. Louisville: Westminster John Knox Press.

Schrijvers, Joeri. 2006. Ontotheological Turnings? Marion, Lacoste and Levinas on the Decentering of Modern Subjectivity. Modern Theology 22: 221-53. [CrossRef]

Serban, Claudia. 2012. La méthode phénoménologique, entre reduction et herméneutique. Les études philosophiques: La méthode phénoménologique aujourd'hui 100: 81-100. [CrossRef]

Winkler, Gabriel. 1978. The Original Meaning of Pre-Baptismal Anointing and its Implications. Worship 52: $24-45$. 